\title{
A Study of Perception and Understanding on Entering to ASEAN Community of Nakhon Ratchasima Citizen in Thailand
}

\author{
Apiradee Kruajeenteng and Khanchitpol Yousapronpaiboon
}

\begin{abstract}
This work aims to study perception and understanding on entering to ASEAN Community (AC) which consists of three pillars: ASEAN Political-Security (APSC), ASEAN Economic (AEC) and ASEAN Socio-Cultural Community (ASCC) of Nakhon Ratchasima Citizen. The study analyzed data collected from 400 questionnaires in Nakhon Ratchasima province. The comparative analysis is conducted on statistical data to test the demographic difference in terms of gender, age and occupation. The result show that perception and understanding of Nakhon Ratchasima citizen on $\mathrm{AC}$ and each sector are at intermediate as follow: AC (3.84), APSC (3.90), AEC (3.82), ASC (3.79) with seven interval scales. Considering on the factors of genders and ages, there is no influence on the perception and understanding on entering to $\mathrm{AC}$ while there is an effect from the different occupations, especially on APSC. In particularly the largest difference of perception and understanding on APSC between occupations is between government officer and employee.
\end{abstract}

Index Terms-ASEAN community, perception, Thailand, understanding,

\section{INTRODUCTION}

As in the high competition level of all countries in the world nowadays, many countries are focusing on the integration and cooperation in the region to increase bargaining power and their competitiveness in the international arena. Similarly to the formation of the AC, caused by the members of the 10 countries in the Southeast Asia region, seem to be a good example of partnership to build up the bargaining power to the international community. The AC has been originally set up since the year 2546. By the year 2563, AC will be comprised with three pillars, namely the ASPC, AEC and ASCC [1]. Nakhon Ratchasima province located in such a geographical location of Northeastern region of Thailand. As a center of transportation and transit between regions, Nakhon Ratchasima establishes itself as the virtual capital of Northeastern area as the center of economic, social, natural resources, environment, and stability [2]. Moreover, Nakhon Ratchasima province shares the greatest manufacturing sector of the country at $47.3 \%$ and carrying the highest rate of growth for the industry.

Therefore development of human resource is highly required corresponding to the growth of industrial demand.

Considering these factors of Nakhon Ratchasima province, it is very interesting that how much Nakhon Ratchasima citizen have their perception and understanding of entering

Manuscript received April 15, 2014; revised June 19, 2014.

The authors are with the College of Graduate Study in Management, Khon Kaen University, Bangkok, Thailand (e-mail: apiradee@slri.or.th,Yousapro@yahoo.com). into the AC in year 2015 [3].

\section{LITERATURE REVIEW}

Schiffman and Kanuk [4] referred that the process of perception of individual person concern on that person has an opportunity to select, organize and interpret on what comes in to stimulate. Result of the process is in forms of individual's meanings and pictures. Difference of the result depends on factors, especially basic knowledge, personal value and expectancy. As in, perception is the principle psychological process of each person. Thus, without the perception, each individual person cannot create memory, idea and knowledge. The perception on any situations is the process that person receive signal from any stimulation via sensations. From that the signal is transferred along nerve network into brain and figured to be the perception [5]. Munn reported that difference of perception can occur from two factors. The first one is External Attention Factor which is the characteristic of the stimulation such as intensities of light, sound or taste. Any person would rather recognize the stronger level of stimulation more than the lighter ones, similar to the size of the objects can draw more attention. Repetition is also the stronger stimulation that only-one-time-occur ones. Finally, people would pay an attention on moving object than the static ones. The second one is Internal Attention Factor which is intrinsic character such as incentive, learning level and personality [6].

Another theory of perception can be shown as in Fig. 1. The perception is the process that individuals organize and interpret their sensory impressions in order to give meaning to their environment. However, the people's perceiving can be different from objective reality. Individual may look at the same thing yet perceive it differently. The context in which they see objects or events is also important [7].

The studied that entering into the AC can cause either positive or negative results based on the level of readiness of citizen in the country. The perception and understanding of citizen on entering into the $\mathrm{AC}$ are the keys to be prompted therefore they can take advantage of this countries' integration [8]. By the study of psychological properties such as memory, intelligence, interest, skill and attitude and physical properties such as gender, age, nationality and level of education are the internal factors influent to the perception of people. In addition, another study indicated that the understanding has been crafted by the level of education and experience [9]. It can be summarized that the understanding is the relationships between the study and the experience of person. It also is the important factor of reading. If the 
understanding cannot occur after the reading, it can be considered that the actual reading has not been occurred. The understanding can be classified into two categories; 1) Instant Understanding which depends on basic knowledge of person on the meaning of what they are reading even on words and idioms, and 2) Discreet Understanding which require surrounding knowledge, skills and varieties of abilities as tools to synthesize the understanding as of what the writer want to transfer, teach, suggest, convince or entertain. This kind of understanding also have the capability of considering, summarize, analysis to find conclusion, meaning and knowledge which mainly rely on the scope and experience of person [10].

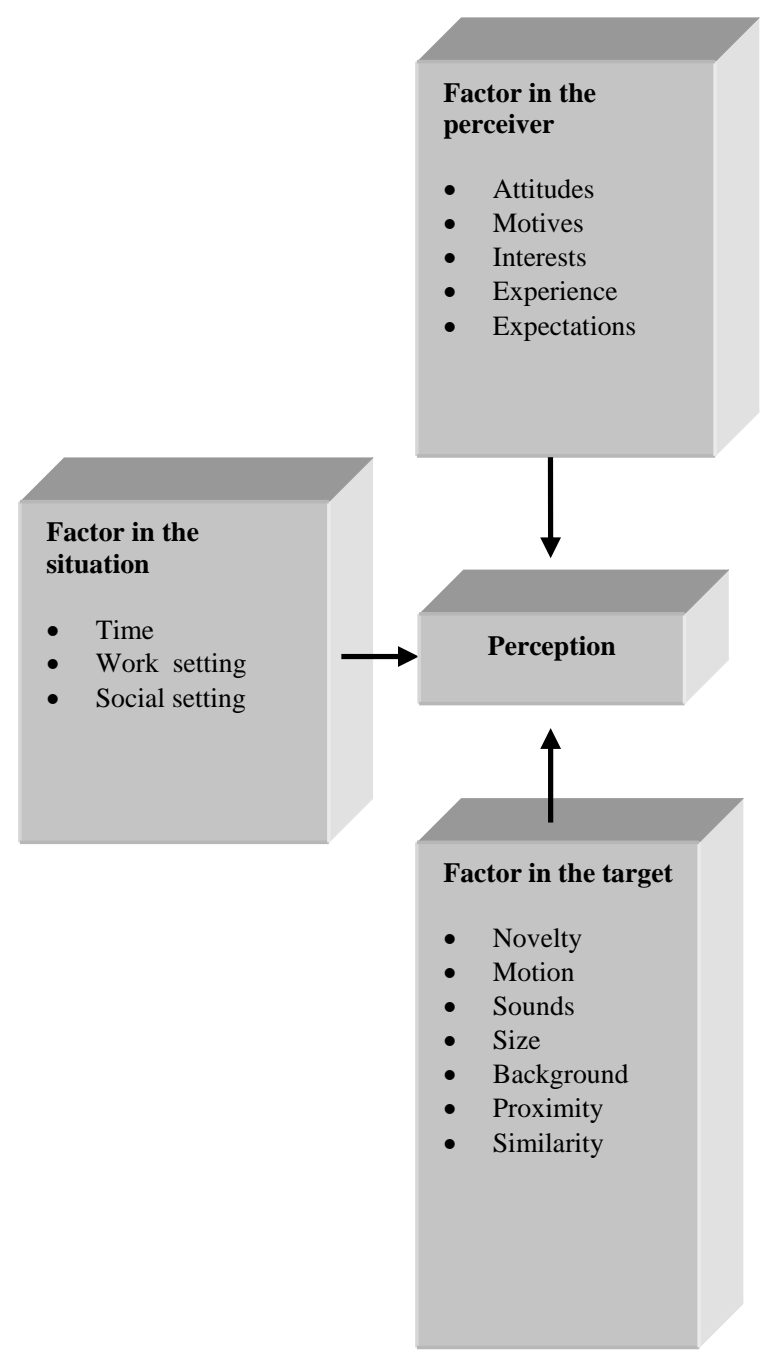

Fig. 1. Factors those influence perception.

The difference on behavior of learning can affect on perception of AEC [11]. Therefore this study has been specified on only factors of gender, age and occupation which influent on the perception and understanding of people on entering to the AC.

\section{OBJECTIVES, MEthodolOGY AND RESEARCH FRAMEWORK AND HYPOTHESIS}

\section{A. Objectives}

This work has reported on the study of perception and understanding of Nakhon Ratchasima province on APSC,
AEC and ASCC as Thailand entering into the AC.

\section{B. Methodology}

This study is based on the way of survey research and using the Close-Ended Questionnaire to collect the data. Samples of Nakhon Ratchasima citizen have been chosen with no limitations of gender, age and occupation. They must be registered with Nakhon Ratchasima Tax office without the necessary of household registration in Nakhon Ratchasima province The questionnaire consisted of three main parts; 1) the permission of data collection, 2) the questions to collect information on the demography consists of genders (male or female), age (less than 28, 26-35, 36-45 and over than 45 years old) and occupations (student, private sector officer, government officer, self-employed, retired and employee), 3) the questions to collect the information of perception and understanding on entering to AC. In this section, the questions have been separated into three parts to focus on the perception and understanding of APSC, AEC and ASCC. All of the questions in these sections are designed in the form of 7 -scale rating corresponds to the levels of perception and understanding. The questionnaire has been evaluated the reliability by using the Cronbach's alpha Analysis Test [12]. By 30 questionnaires, the test gives the Cronbach's alpha coefficient to be 0.94 . After that the questionnaires have been distributed to universities, commercial and residential areas of Nakhon Ratchasima province aiming to collect 400 questionnaires. The data collection has been preceded in March, 2014.

\section{Research Framework and Hypothesis}

According to the theory of perception and understanding, this study has been designed to find out the effect on the differences of perception and understanding on entering to AC and specify on APSC, AEC and ASCC of Nakhon Ratchasima citizen. This study has been focus on only three physical properties; gender, age and occupation. The schematic diagram of the framework has been shown as in Fig. 2.

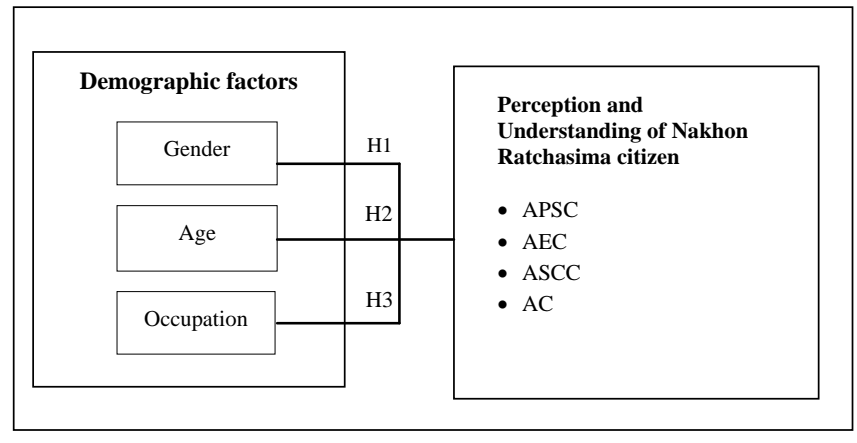

Fig. 2. Research framework.

\section{RESUlT}

Analysis of 400 questionnaires shows the distributions of frequencies and percentages among gender, age, occupation as in Table I.

The result of perception and understanding on APSC, AEC and ASCC are shown in Table II. 
TABLE I: THE DisTRIBUTIONS OF FREQUENCIES AND PERCENTAGES AMONG GENDER, AGE AND OCCUPATION OF THE SAMPLES

\begin{tabular}{lcc}
\hline \hline & Frequency & Percentage (\%) \\
\hline Gender & 154 & 38.75 \\
Male & 245 & 61.25 \\
Female & & \\
\hline Age & 94 & 23.50 \\
less than 28 & 91 & 22.75 \\
$28-35$ & 153 & 38.25 \\
36-45 & 62 & 15.50 \\
Over than 45 & 104 & 26.00 \\
\hline Occupation & 101 & 25.25 \\
Student & 123 & 30.75 \\
Private Sector & 9.75 \\
officer & 39 & 5.25 \\
Self-employed & 21 & 3.00 \\
Retired & 12 & \\
Employee & & \\
\hline \hline
\end{tabular}

TABLE II: PERCEPTION AND UNDERSTANDING ON ENTERING TO AC, ASPC, AEC AND ASCC OF NAKHON RATCHASIMA CITIZEN

\begin{tabular}{cccc}
\hline & Rate & S.D. & Level \\
\hline ASPC & 3.90 & 1.143 & intermediate \\
AEC & 3.82 & 1.154 & Intermediate \\
ASCC & 3.79 & 1.222 & Intermediate \\
AC & 3.84 & 1.116 & intermediate \\
\hline \hline
\end{tabular}

According to the analysis, the hypothesis of genders and ages can give rise to the difference of perception and understandings on entering to $\mathrm{AC}$ are rejected. In contrast, the different occupations can occur to the different of perception and understanding, especially on ASCC pillar. The result has been demonstrated as in Table III.

To be more specific, the relation of perception and understanding on entering to AC; ASCC and occupations has been analyzed by the Least Significant Difference (LSD) method. The result of LSD analysis on different occupations has been shown as in Table IV.

TABLE III: COMPARISON OF THE AVERAGE PERCEPTION AND UNDERSTANDING ON ENTERING TO AC BETWEEN THE DIFFERENT OCCUPATION

\begin{tabular}{|c|c|c|c|c|c|c|c|c|}
\hline & & & & Avera & Rate & & & \\
\hline $\begin{array}{c}\text { Rate of } \\
\text { perception and } \\
\text { understanding }\end{array}$ & 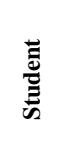 & 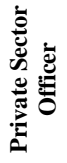 & 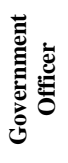 & 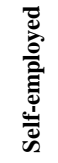 & 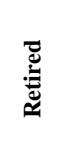 & 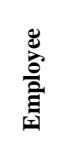 & $F$ & Sig. \\
\hline ASPC & 4.16 & 3.94 & 3.72 & 3.51 & 4.27 & 3.87 & $3.14 *$ & 0.01 \\
\hline $\mathrm{AEC}$ & 4.01 & 3.87 & 3.74 & 3.42 & 4.02 & 3.67 & 1.81 & 0.11 \\
\hline ASCC & 3.97 & 3.78 & 3.74 & 3.37 & 4.09 & 3.65 & 1.75 & 0.12 \\
\hline $\mathrm{AC}$ & 4.05 & 3.86 & 3.73 & 3.43 & 4.13 & 3.73 & $2.33^{*}$ & 0.04 \\
\hline
\end{tabular}

*statistical significant lower than 0.05 .
TABLE IV: THE COMPARISON OF THE DIFFERENCE OF PERCEPTION AND UNDERSTANDING ON ENTERING TO AC; APSC BETWEEN THE DIFFERENT OCCUPATION

\begin{tabular}{|c|c|c|c|c|c|c|c|}
\hline \multirow[t]{2}{*}{ Occupation } & & $\begin{array}{l}\vec{E} \\
\stackrel{\Xi}{E}\end{array}$ & 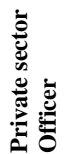 & 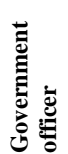 & 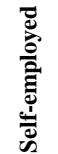 & 党 & 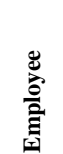 \\
\hline & $\mathrm{x}$ & 4.01 & 3.87 & 3.74 & 3.42 & 4.02 & 3.67 \\
\hline Student & 4.01 & - & 0.14 & 0.27 & 0.58 & -0.02 & 0.34 \\
\hline $\begin{array}{l}\text { Private sector } \\
\text { Officer }\end{array}$ & 3.87 & & - & 0.13 & 0.44 & -0.15 & 0.20 \\
\hline $\begin{array}{l}\text { Government } \\
\text { officer }\end{array}$ & 3.74 & & & - & 0.31 & -0.29 & $0.07 *$ \\
\hline Self-employed & 3.42 & & & & - & -0.60 & -0.24 \\
\hline Retired & 4.02 & & & & & - & 0.35 \\
\hline Employee & 3.67 & & & & & & - \\
\hline
\end{tabular}

The study of perception and understanding on entering to AC on the three pillars; APSC, AEC and ASCC projected on the different of genders, ages and occupations found that Nakhon Ratchasima citizen have the perception and understanding on all three pillars at the intermediate level. The result reflects on urgent requirement on knowledge transfer of $\mathrm{AC}$ to the citizen in this area. With the different occupations can cause to the different level of perception and understanding, ASCC is the pillar that has the most relevant to variety of occupations. Among the occupations, the government officer and employee have the largest difference on the perception and understanding on APSC. This result consists to the work of [13] and [14]. The conclusion of work has been illustrated as in Table V.

TABLE V: CONCLUSIONS OF THE HYPOTHESIS

\begin{tabular}{ccc}
\hline \hline Hypothesis & Result & Statistical Tests \\
\hline Gender & Rejected & Sample t-test \\
Age & Rejected & One - way ANOVA \\
Occupation & Accepted & One - way ANOVA \\
\hline \hline
\end{tabular}

\section{FUTURE RESEARCH}

The next study should focus on each of pillars such as APSC, AEC or ASCC by using the open-ended questionnaire. This type of data collection method should be suitable for collecting variety of opinion. The way of obtaining the data might be by the method of interview.

Strategic plan should be relied on promotion and and publication of the knowledge of AC as a marketing strategy [13], [14]. Knowledge Management and Event Communication should be chosen such as arrange an event, a communication or books those consist of details on AC for Nakhon Ratchasima citizen. More examples of the actions may be in the form of advertisement, and billboards. In this case, the advertisement on television might be the recommended option as it comprised of vision and sound. However the simple way to present and directly deliver the 
knowledge to the target is the key which cannot be neglected [15].

\section{REFERENCES}

[1] Departmant of Trade Negotiations, ASEAN Economics Community, Ministry of Commerce, Ministry of Foreign Affairs, 2011.

[2] S. Sakda, International Business Management, $7^{\text {th }}$ ed., Thailand: Pearson Education, Ltd., 2012.

[3] Council Ratchasima Province, 2008.

[4] L. G. Schiffman and L. Kanuk, Consumer Behavior, $4^{\text {th }}$ ed., New York, Prentice-Hall International, 1991.

[5] P. H. Lindsay and D. A. Norman, Human Information Processing, $2^{\text {nd }}$ ed., New York, Academic Press, 1977.

[6] N. L. Munn, Psychology, $5^{\text {th }}$ ed., Boston, Houghton Mifflin Com., pp. 497-499, 1966

[7] S. P. Robbins, T. A. Judge, A. Odendaal, and G. Roodt, Organisational Behavior Global and Southern African Perspectives, $2^{\text {nd }}$ ed., Capetown, Southe Africa: Pearson: v, pp.119

[8] T. Choksuchat, ASEAN Economic Community: the Importance and Thai Preparation, HCU journal, vol. 14, no. 27, pp. 14, 2010.

[9] K. L. Udomlak, Product Factors and Integrated Marketing Communication Influencing Behavior and Trendency of Purchasing the ACER Computers (Notebooks) of Organizations, Bangkok Metropolitan Area, Srinakharinwirot University, 2006.

[10] S. Senchowanich, Techniques for English Reading, Bangkok, Thammasart University Publishing, 1987.

[11] K. Somrak, "Media exposure, knowledge, attitude and behavior trend toward ASEAN economic community (AEC)," Journal of Mass Communication, Thammasart University, 2012.

[12] L. J. Cronbach, "Coefficient alpha and the internal structure of tests," Psychometrika, vol. 16, no. 3, pp. 297-334, 1951.

[13] K. Dissawat, Enterpreneurs's Perception on ASEAN Economic Community (AEC): a Case Study of Business Enterprise in the THAI-LAOS Border Trade, Khon Kaen University, Bangkok Campus, 2013.
[14] K. Yousapronpaiboon, Marketing Management Strategy, College of Graduate Study in Management, Khon Kaen University, Bangkok Campus, 2013.

[15] S. Jintana, "The marketing," The Marketing Communication Perception and Attitudes of People on Muang Thai Life Assurance Company in Bangkok Metropolitan Region, 2009.

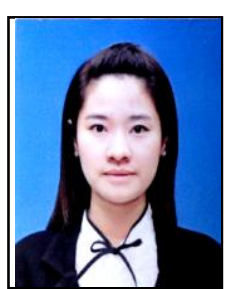

Apiradee Kruajeenteng was born on December 7, 1980 in Bangkok. Before her graduate study in management, Khon Kaen University, Bangkok, she graduated bachelor degree on business computer from Siam University, Bangkok in 2002. She worked at Office of the Permanent Secretary, the prime minister's office of the computer technical officer, the Hitachi Transport System (Thailand), Co., Ltd. currently, she is working as a human resource officer at the Synchrotron Light Research Institute (Public Organization), Ministry of Science And Technology, Thailand.

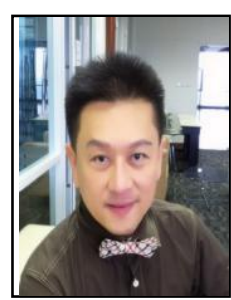

Khanchitpol Yousapronpaiboon served as an assistant professor of marketing at College of Graduate Study in management in Khon Kaen University for 14 years, where he taught marketing management and service marketing management courses at master and doctoral levels. He received an excellence teaching award of Khon Kaen University in 2003. He gained his DBA from Nova Southeastern University of the $H$. Wayne Huizenga's School of business \& entrepreneurship. He worked in Bangkok Bank Public Company Limited for 10 years. He is an honorary advisor; the secretary of the senate standing committee on education; and sub-standing committee on the follow up and evaluation preparation of ASEAN community, the senate standing committee on education in Thailand. $\mathrm{He}$ is also a part-time lecturer of marketing management and service marketing management courses at Chiang Mai University and Ubon Ratchatani University in Thailand. 